\title{
Survey of Zoonotic Trematode Metacercariae in Fish from Water systems of Geum-gang (River) in Republic of Korea
}

\author{
Woon-Mok Sohn ${ }^{1 * *} \mathbb{C}^{\oplus}$, Byoung-Kuk Na1 ${ }^{1}$, Shin-Hyeong $\mathrm{Cho}^{2}$, Cheon-Hyeon $\mathrm{Kim}^{3}$, Min-Ah Hwang ${ }^{3}$, \\ Kyeong-Woo No ${ }^{3}$, Jai-Dong Kim ${ }^{4}$ \\ 'Department of Parasitology and Tropical Medicine, and Institute of Health Sciences, Gyeongsang National University School of Medicine, Jinju \\ 52727, Korea; ' 2 Division of Vectors and Parasitic Diseases, Centers for Disease Control and Prevention, Osong 28159, Korea; ${ }^{3}$ Division of \\ Microorganism, Jeollabuk-do Institute of Health and Environment, Imsil 55928, Korea; ${ }^{4}$ Division of Microbiology, Chungcheongnam-do Institute of \\ Health and Environment, Hongseong 32254, Korea
}

\begin{abstract}
The infection status of zoonotic trematode metacercariae (ZTM) was surveyed in freshwater fishes from the water systems of Geum-gang (River) in the Republic of Korea (Korea). A total of 1,161 freshwater fishes from 6 local sites of Geum-gang were examined with the artificial digestion method for 4 years (2012-2015). Clonorchis sinensis metacercariae were detected in 122 (37.2\%) out of 328 fishes in the positive fish species from 4 surveyed areas, and their mean intensity was 43 per fish infected. Metagonimus spp. metacercariae were found in $432(51.7 \%)$ out of 835 fishes in the positive fish species from all 6 surveyed areas, and their mean intensity was 30 per fish infected. Centrocestus armatus metacercariae were detected in $285(75.0 \%)$ out of 380 fishes in the positive fish species from 6 surveyed areas, and their mean intensity was 2,100 per fish infected. Echinostoma spp. metacercariae were found in 56 (19.7\%) out of 284 fishes in the positive fish species from 5 surveyed areas, and their mean intensity was 10 per fish infected. Clinostomum complanatum metacercariae were detected in 98 (57.3\%) out of 171 fishes in the positive fish species from only 2 surveyed areas, and their mean intensity was 11 per fish infected. Conclusively, the endemicity of ZTM is not so high in fishes from water systems of Geum-gang in Korea although it is more or less different by fish species, surveyed areas and ZTM species.
\end{abstract}

Key words: Zoonotic trematode metacercaria, Clonorchis sinensis, Metagonimus spp., Centrocestus armatus, Echinostoma spp., Clinostomum complanatum, Geum-gang

\section{INTRODUCTION}

Nowadays, fishborne zoonotic trematodes (FZT) including Clonorchis sinensis are the most important helminth group in the Republic of Korea (Korea) [1]. A team of Korean CDCP (Centers for Disease Control and Prevention) has performed the control project for zoonotic trematode infections in some endemic areas, especially, riverside areas of 7 major rivers, i.e., Han-gang (gang means river), Geum-gang, Mangyeong-gang, Yeongsan-gang, Tamjin-gang, Seomjin-gang and Nakdonggang, in Korea [2-5]. The co-working groups of CDCP have also examined freshwater fishes, the infection sources of FZT, from the water systems of major rivers in Korea to reveal the

\footnotetext{
- Received 3 December 2020, revised 7 January 2021, accepted 11 January 2021.

*Corresponding author (wmsohn@gnu.ac.kr)

(c) 2021, Korean Society for Parasitology and Tropical Medicine

This is an Open Access article distributed under the terms of the Creative Commons Attribution Non-Commercial License (https://creativecommons.org/licenses/by-nc/4.0) which permits unrestricted non-commercial use, distribution, and reproduction in any medium, provided the original work is properly cited.
}

infection status of zoonotic trematode metacercariae (ZTM) [6-13].

Many Korean workers have performed epidemiological surveys on the infection status of ZTM in freshwater fishes, the human infection sources, from a variety of ecological environments, i.e., river, stream, lake, pond and swamp, to estimate the endemicities of ZTM [6-14]. Especially, Cho et al. [6] investigated the infection status of $C$. sinensis metacercariae (CsMc) in freshwater fish from 3 wide regions, which were tentatively divided by the latitudinal levels of the Korean peninsula. Cho et al. [7] also surveyed on the infection status of ZTM in freshwater fish from Gangwon-do (do=Province), Korea. Sohn et al. [8] investigated the infection status of digenetic trematode metacercariae (DTM) including C. sinensis in freshwater fish from the water systems of Hantan-gang and Imjin-gang in northern regions of Korea. Sohn et al. [9] and Yoon et al. [10] reported the infection status of CsMc in freshwater fishes from the water systems of Seomjin-gang and Tamjin-gang. Sohn et al. $[11,12]$ also reported the infection status of CsMc in fresh- 
water fish from 2 highly endemic sites, Wi-cheon (cheon means stream) and Yang-cheon (branch streams of Nakdonggang), in Gunwi-gun (gun=county), Gyeongsangbuk-do and Sancheong-gun, Gyeongsangnam-do, Korea. Recently, Sohn and $\mathrm{Na}$ [14] described the infection status of DTM in freshwater fishes from 2 visiting sites, Junam-jeosuji (jeosuji means reservoir) and Woopo-neup (neup means swamp), of migratory birds in Gyeongsangnam-do, Korea. Sohn et al. [13] also reported the infection status with DTM in fishes from coastal lakes in Gangwon-do, Korea.

Geum-gang is one of the major rivers in Korea, which originates in Jangsu-gun, Jeollabuk-do. It flows northward through Jeollabuk-do and Chungcheongbuk-do and then changes direction in the vicinity of Daejeon Metropolitan City, and flows southwest through Chungcheongnam-do and reaches the Yellow Sea near Gunsan-si, (si = city) Jeollabuk-do. This river has many tributary streams including Yugu-cheon and Nonsancheon [15]. On the other hand, several epidemiological studies have been performed to investigate the infection status of zoonotic trematodes, i.e., C. sinensis and Metagonimus spp., in the riverside areas of Geum-gang [16-21]. However, studies on the infections of ZTM in fish hosts were not enough. Kim [16] and Kim et al. [17] studied on the epidemiological and biological characteristics of Metagonimus sp. fluke, which was prevalent in the adjacent areas of Geum-gang at 1980's. Recently, Choe et al. [21] surveyed the infection status of DTM in 2 exotic fish species, Micropterus salmoides and Lepomis macrochirus, and some species of freshwater fish from 2 sites of Geum-gang in Chungcheongbuk-do, Korea. The large-scale survey on the infection status with ZTM in a variety of fish species has not been conducted yet in the areas of Geum-gang. Therefore, in the present study, we investigated the infection status of ZTM in freshwater fishes from 6 sites of Geum-gang in Jeollabuk-do and Chungcheongnam-do for 4 years (2012-2015).

\section{MATERIALS AND METHODS}

\section{Fish collection sites}

We collected total 1,161 freshwater fishes in 6 local sites of Geum-gang, i.e., Juja-cheon (Latitude: 35.980225; Longitude: 127.393880) in Jinahn-gun, Geum-gang (35.975291; 127.556624) in Muju-gun, Jeollabuk-do, Geum-gang (36.114265; 127.587748) in Geumsan-gun, Yugu-cheon $(36.537272 ; 126.948474)$ in Gongju-si, Ji-cheon (36.389576; 126.851738) in Cheongyanggun, Nonsan-cheon $(36.199058 ; 127.067899)$ in Nonsan-si,

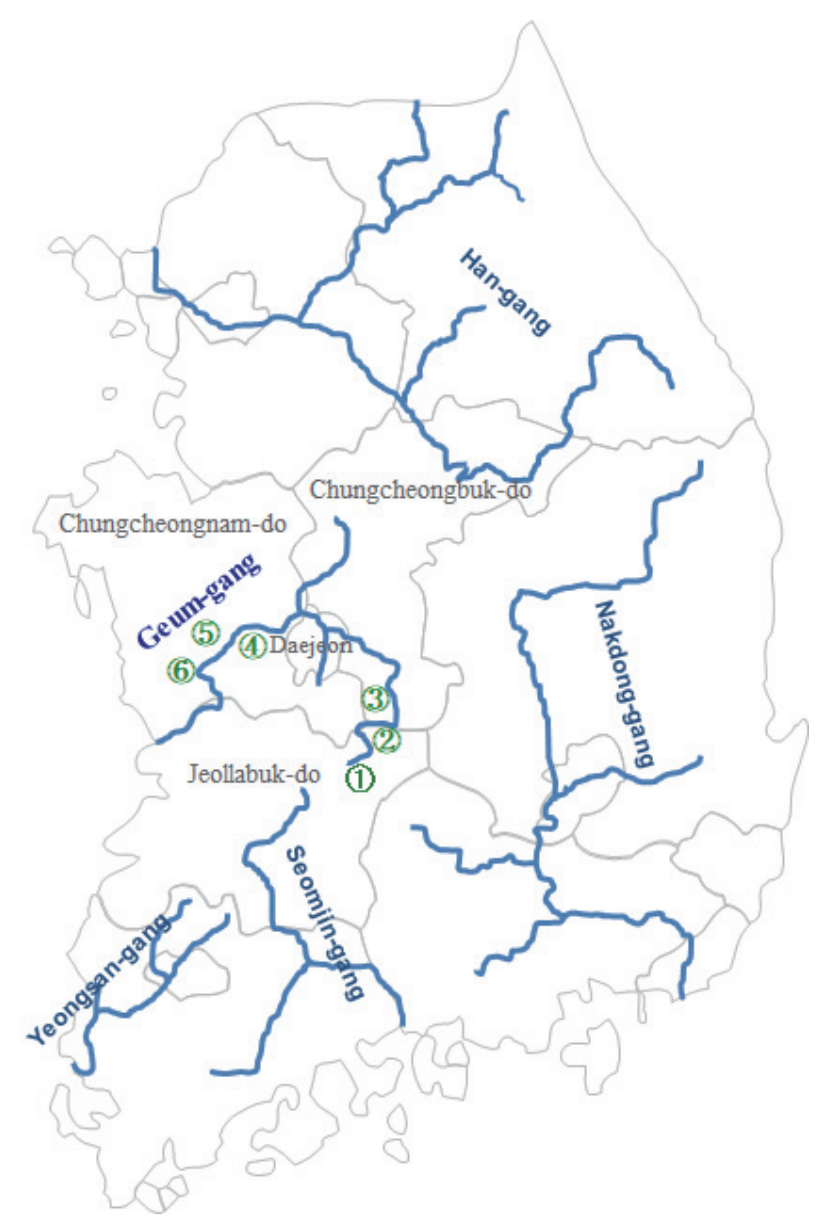

Fig. 1. The surveyed areas in the water systems of Geum-gang (River) in Jeollabuk-do and Chungcheongnam-do, Korea: (1) Jujacheon in Jinahn-gun, (2) Geum-gang in Muju-gun, Jeollabuk-do, (3) Geum-gang in Geumsan-gun, (4) Yugu-cheon in Gongju-si, (5) Jicheon in Cheongyang-gun, (6) Nonsan-cheon in Nonsan-si, Chungcheongnam-do, Korea.

Chungcheongnam-do, for 4 years (2012-2015) (Fig. 1).

\section{Fishes examined}

Total 208 freshwater fish (18 species) from Juja-cheon in Jinahn-gun, Jeollabuk-do were examined in 2012. Species of fish examined (No. of fish) were Zacco platypus (40), Zacco temminckii (40), Pungtungia herzi (25), Hemibarbus longirostris (22), Odontobutis platycephala (22), Squalidus gracilis majimae (16), Pseudogobio esocinus (10), Iksookimia longicorpus (8), Acheilognathus koreensis (7), Microphysogobio koeensis (5), Iksookimia hugowolfeldi (3), Liobagrus obesus (2), Silurus asotus (2), Pseudobagrus koreanus (2), Misgurnus anguillicaudatus (1), Pseudopungtungia nigra (1), Rhynchocypris oxycephalus (1), Carassius auratus (1). In Geum-gang in Muju-gun, Jeollabuk-do, a total of 123 
fishes (14 spp.) were examined in 2012. Species of fish examined (No. of fish) were P. herzi (35), P. koreanus (25), Coreoperca herzi (20), Z. temminckii (11), P. esocinus (10), Pseudobagrus brevicorpus (10), H. longirostris (4), Sarcocheilichthys variegatus wakiyae (2), Acheilognathus lanceolatus (1), P. nigra (1), O. platycephala (1), C. auratus (1), Pseudobagrus fulvidraco (1), Siniperca scherzeri (1).

Total 386 freshwater fish (22 species) from Geum-gang in Geumsan-gun were examined for 3 years (2013-2015). Species of fish examined (No. of fish) were P. esocinus (76), H. longirostris (67), Z. platypus (38), C. herzi (38), Z. temminckii (33), O. platycephala (23), C. auratus (20), P. herzi (15), Acheilognathus yamatsutae (11), Liobagrus mediadiposalis (10), Acheilognathus majusculus (10), Squalidus japonicus coreanus (10), Sarcocheilichthys nigripinnis morii (8), S. scherzeri (7), Coreoleuciscus splendidus (5), S. variegatus wakiyae (4), Opsariichthys uncirostris amurensis (4), Hemibarbus labeo (3), Micropterus salmoides (1), S. gracilis majimae (1), Acanthorhodeus gracilis (1), Abbottina springeri (1). In the Yugu-cheon in Gongju-si, a total of 311 fishes (14 spp.) were examined in 2013 and 2015. Species of fish examined (No. of fish) were A. lanceolatus (72), Z. platypus (59), $H$. longirostris (32), P. esocinus (28), P. herzi (22), A. yamatsutae (20), O. uncirostris amurensis (18), C. auratus (17), Acheilognathus rhombeus (15), O. platycephala (10), A. springeri (7), S. variegatus wakiyae (5), H. labeo (5), S. gracilis majimae (1).

Total 89 freshwater fish (13 spp.) from Ji-cheon in Cheongyang-gun were examined in 2014. Species of fish examined (No. of fish) were Z. temminckii (29), H. longirostris (13), P. esocinus (11), S. scherzeri (11), A. koreensis (10), Z. platypus (4), P. herzi (3), C. auratus (3), S. nigripinnis morii (1), O. platycephala (1), Iksookimia koreensis (1), P. koreanus (1), P. fulvidraco (1). In the Nonsan-cheon in Nonsan-si, a total of 44 fishes (11 spp.) were examined in 2013. Species of fish examined (No. of fish) were Lepomis macrochirus (10), C. auratus (10), O. uncirostris amurensis (7), Hemiculter eigenmanni (6), S. scherzeri (3), Pseudorasbora parva (2), M. salmoides (2), P. herzi (1), Hemiculter leucisculus (1), S. variegatus wakiyae (1), P. esocinus (1).

\section{Method of fish examination}

All collected fishes with ice were transferred to the laboratory of Department of Parasitology and Tropical Medicine, Gyeongsang National University College of Medicine, Jinju, Korea. Their length and weight were individually measured and identified the fish species [22]. Individual fish was finely ground in a mortar with pestle, the ground fish meat was mixed with artificial gastric juice, and the mixture was incubated at $36^{\circ} \mathrm{C}$ for about $2 \mathrm{hr}$. The digested material was filtered with $1 \times 1 \mathrm{~mm}^{2}$ of mesh, and washed with $0.85 \%$ saline until the supernatant became clear. The sediment was carefully examined under a stereomicroscope. The metacercariae of each species (only ZTM) were separately collected viewing from the general feature, and were counted to get hold of the prevalence (\%) and intensity of infection (No. of ZTM per fish infected) by fish species $[23,24]$.

\section{RESULTS}

The metacercariae of $C$. sinensis were detected in 122 (37.2\%) out of 328 fishes in the positive fish species from 4 surveyed areas, i.e., Geum-gang in Muju-gun, Jeollabuk-do, and Geumgang in Geumsan-gun, Ji-chen in Cheongyang-gun and Nonsan-cheon in Nonsan-si, Chungcheongnam-do. Their mean intensity of infection was 43 per fish infected. Especially, in striped shiner, P. herzi, from Geum-gang in Muju-gun, Jeollabuk-do and in Geumsan-gun, Chungcheongnam-do, the prevalences were $97.1 \%$ and $100 \%$, and the mean intensity of infection was 95 and 98 per fish infected. The infection status by the fish species and surveyed areas was shown in Table 1 in detail.

The metacercariae of Metagonimus spp. were found in 432 (51.7\%) out of 835 fishes in the positive fish species from 6 surveyed areas, and their mean intensity of infection was 30 per fish infected. Especially, in goby minnow, Pseudogobio esocinus, from Geum-gang in Geumsan-gun, Chungcheongnamdo, the prevalence was $98.7 \%$ and the mean intensity of infection was 86 per fish infected. The infection status by the fish species and surveyed areas was designated in Table 2 in detail.

The metacercariae of Centrocestus armatus were detected in $285(75.0 \%)$ out of 380 fishes in the positive fish species from 6 surveyed areas, and their mean intensity of infection was 2,100 per fish infected. Especially, in pale chub, Zacco platypus, from Yugu-cheon in Gongju-si, and Geum-gang in Geumsangun, Chungcheongnam-do, the prevalences were $100 \%$ in each and the mean intensity of infection were more than 7,000 and 3,300 per fish infected. The infection status by the fish species and surveyed areas was revealed in Table 3 in detail.

The metacercariae of Echinostoma spp. were detected in 56 (19.7\%) out of 284 fishes in the positive fish species from 5 surveyed areas, and their mean intensity of infection was 10 per fish infected. Especially, in Korean dark sleeper, O. platy- 
Table 1. Infection status of Clonorchis sinensis metacercariae (CsMc) in freshwater fish from Geum-gang in Jeollabuk-do and Chungcheongnam-do, Korea

\begin{tabular}{|c|c|c|c|c|}
\hline \multirow{2}{*}{ Locality and fish sp. } & \multirow{2}{*}{$\begin{array}{c}\text { No. of } \\
\text { fish examined }\end{array}$} & \multirow{2}{*}{$\begin{array}{l}\text { No. (\%) of } \\
\text { fish infected }\end{array}$} & \multicolumn{2}{|c|}{ No. of CsMc detected } \\
\hline & & & Range & Average \\
\hline \multicolumn{5}{|c|}{ Geum-gang in Muju-gun, Jeollabuk-do } \\
\hline Pungtungia herzi & 35 & $34(97.1)$ & $1-141$ & 95.2 \\
\hline Sarcocheilichthys variegatus & 2 & $2(100)$ & $6-11$ & 8.5 \\
\hline Siniperca scherzeri & 1 & $1(100)$ & - & 2.0 \\
\hline Subtotal & 38 & 37 (97.4) & $1-141$ & 88.0 \\
\hline \multicolumn{5}{|l|}{ Geum-gang in Geumsan-gun } \\
\hline Pseudogobio esocinus & 76 & $4(5.3)$ & $1-2$ & 1.3 \\
\hline Hemibarbus longirostris & 67 & $19(28.4)$ & $1-2$ & 1.2 \\
\hline Zacco platypus & 38 & $2(5.3)$ & - & 1.0 \\
\hline Pungtungia herzi & 15 & $15(100)$ & $3-924$ & 98.1 \\
\hline Acheilognathus yamatsutae & 11 & $2(18.2)$ & - & 1.0 \\
\hline Squalidus japonicus coreanus & 10 & $8(80.0)$ & $1-15$ & 4.6 \\
\hline Sarcocheilichthys nigripinnis & 8 & $7(87.5)$ & $1-69$ & 14.4 \\
\hline Coreoleuciscus splendidus & 5 & $2(40.0)$ & $1-6$ & 3.5 \\
\hline Sarcocheilichthys variegatus & 4 & $4(100)$ & $2-22$ & 13.5 \\
\hline Squalidus gracilis majimae & 1 & $1(100)$ & - & 28.0 \\
\hline Subtotal & 235 & $64(27.2)$ & $1-924$ & 27.0 \\
\hline \multicolumn{5}{|l|}{ Ji-cheon in Cheongyang-gun } \\
\hline Hemibarbus longirostris & 13 & $7(53.9)$ & $1-3$ & 1.9 \\
\hline Pseudogobio esocinus & 11 & $1(9.1)$ & - & 3.0 \\
\hline Siniperca scherzeri & 11 & $2(18.2)$ & $1-2$ & 1.5 \\
\hline Pungtungia herzi & 3 & $3(100)$ & $8-81$ & 50.7 \\
\hline Sarcocheilichthys nigripinnis & 1 & $1(100)$ & - & 63.0 \\
\hline Subtotal & 39 & $14(35.9)$ & $1-81$ & 16.7 \\
\hline \multicolumn{5}{|l|}{ Nonsan-cheon in Nonsan-si } \\
\hline Opsariichthys uncirostris & 7 & $1(14.3)$ & - & 1.0 \\
\hline Hemiculter eigenmanni & 6 & $4(66.7)$ & $1-3$ & 2.0 \\
\hline Pseudorasbora parva & 2 & $1(50.0)$ & - & 2.0 \\
\hline Sarcocheilichthys variegatus & 1 & $1(100)$ & - & 1.0 \\
\hline Subtotal & 16 & $7(43.8)$ & $1-3$ & 1.7 \\
\hline Total & 328 & $122(37.2)$ & $1-924$ & 42.9 \\
\hline
\end{tabular}

cephala, from Yugu-cheon, the prevalence was 100\% and the mean intensity of infection was 48 per fish infected. The infection status by the fish species and surveyed areas was shown in Table 4 in detail.

The metacercariae of Clinostomum complanatum were detected in 98 (57.3\%) out of 171 fishes in the positive fish species from only 2 surveyed areas, i.e., Geum-gang in Geumsan-gun and Yugu-cheon in Gongju-si, Chungcheongnam-do. Their mean intensity of infection was 11 per fish infected. Especially, in Korean stripted bitterling, Acheilognathus yamatsutae, from Yugu-cheon, the prevalence was $95.0 \%$ and the mean intensity of infection was 18 per fish infected. The infection status by the fish species and surveyed areas was designated in Table 5 in detail.

\section{DISCUSSION}

In the present study, more than 5 species of ZTM, i.e., C. sinensis, Metagonimus spp., C. armatus, Echinostoma spp. and C. complanatum, were detected in fishes from the water systems of Geum-gang, but their endemicities were not so high. The metacercariae of $C$. sinensis were found in fishes from 4 out of 6 survey regions, and their overall prevalence and intensity of infection were $37.2 \%$ and 43 per fish infected in positive fish species. Metagonimus spp. metacercariae were detected in $51.7 \%$ fishes in positive fish species from 6 all survey regions, but their mean intensity was about 30 per fish infected. The metacercariae of $C$. armatus were found in fishes from all 6 survey regions, and they were heavily infected in pale chubs, $Z$. platypus, from Yugu-cheon in Gongju-si and Geum-gang in 
Table 2. Infection status of Metagonimus spp. metacercariae (MsMc) in freshwater fish from Geum-gang in Jeollabuk-do and Chungcheongnam-do, Korea

\begin{tabular}{|c|c|c|c|c|}
\hline \multirow{2}{*}{ Locality and fish sp. } & \multirow{2}{*}{$\begin{array}{c}\text { No. of } \\
\text { fish examined }\end{array}$} & \multirow{2}{*}{$\begin{array}{l}\text { No. (\%) of } \\
\text { fish infected }\end{array}$} & \multicolumn{2}{|c|}{ No. of MsMc detected } \\
\hline & & & Range & Average \\
\hline \multicolumn{5}{|c|}{ Juja-cheon in Jinahn-gun, Jeollabuk-do } \\
\hline Zacco platypus & 40 & $22(55.0)$ & $1-25$ & 6.0 \\
\hline Zacco temminckii & 40 & $33(82.5)$ & $1-16$ & 3.9 \\
\hline Pungtungia herzi & 25 & $4(16.0)$ & $1-2$ & 1.3 \\
\hline Hemibarbus longirostris & 22 & $4(18.2)$ & $1-2$ & 1.3 \\
\hline Squalidus gracilis majimae & 16 & $3(18.8)$ & $1-8$ & 3.7 \\
\hline Pseudogobio esocinus & 10 & $1(10.0)$ & - & 2.0 \\
\hline Microphysogobio koeensis & 5 & $1(20.0)$ & - & 1.0 \\
\hline Subtotal & 158 & $68(43.0)$ & $1-25$ & 4.2 \\
\hline \multicolumn{5}{|c|}{ Geum-gang in Muju-gun, Jeollabuk-do } \\
\hline Pungtungia herzi & 35 & $2(5.7)$ & $1-2$ & 1.5 \\
\hline Zacco temminckii & 11 & $3(27.3)$ & - & 1.0 \\
\hline Pseudogobio esocinus & 10 & $8(80.0)$ & $1-10$ & 3.5 \\
\hline Hemibarbus longirostris & 4 & $2(50.0)$ & - & 1.0 \\
\hline Subtotal & 60 & $15(25.0)$ & $1-10$ & 2.4 \\
\hline \multicolumn{5}{|l|}{ Geum-gang in Geumsan-gun } \\
\hline Pseudogobio esocinus & 76 & $75(98.7)$ & $1-457$ & 85.7 \\
\hline Hemibarbus longirostris & 67 & $66(98.5)$ & $1-82$ & 18.4 \\
\hline Zacco platypus & 38 & $37(97.4)$ & $7-275$ & 74.3 \\
\hline Zacco temminckii & 33 & $25(75.8)$ & $1-53$ & 10.0 \\
\hline Pungtungia herzi & 15 & $8(53.3)$ & $1-3$ & 1.8 \\
\hline Acheilognathus yamatsutae & 11 & 7 (63.6) & $1-11$ & 4.7 \\
\hline Acheilognathus majusculus & 10 & $9(90.0)$ & $3-23$ & 7.1 \\
\hline Squalidus japonicus coreanus & 10 & $4(40.0)$ & $1-3$ & 2.3 \\
\hline Sarcocheilichthys nigripinnis & 8 & $3(37.5)$ & $1-3$ & 2.3 \\
\hline Opsariichthys uncirostris & 4 & $4(100)$ & $4-127$ & 52.0 \\
\hline Sarcocheilichthys variegatus & 4 & $2(50.0)$ & $1-2$ & 1.5 \\
\hline Acanthorhodeus gracilis & 1 & $1(100)$ & - & 4.0 \\
\hline Subtotal & 277 & $241(87.0)$ & $1-457$ & 45.6 \\
\hline \multicolumn{5}{|l|}{ Yugu-cheon in Gongju-si } \\
\hline Acheilognathus lanceolatus & 72 & $1(1.4)$ & - & 1.0 \\
\hline Zacco platypus & 59 & $37(62.7)$ & $1-6$ & 2.9 \\
\hline Hemibarbus longirostris & 32 & $9(28.1)$ & $1-14$ & 3.3 \\
\hline Pungtungia herzi & 22 & $1(4.6)$ & - & 1.0 \\
\hline Acheilognathus yamatsutae & 20 & $1(5.0)$ & - & 1.0 \\
\hline Opsariichthys uncirostris & 18 & $1(5.6)$ & - & 1.0 \\
\hline Carassius auratus & 17 & $1(5.9)$ & - & 9.0 \\
\hline Acheilognathus rhombeus & 15 & $1(6.7)$ & - & 1.0 \\
\hline Sarcocheilichthys variegatus & 5 & $4(80.0)$ & $1-6$ & 2.5 \\
\hline Subtotal & 260 & $56(21.5)$ & $1-14$ & 2.9 \\
\hline \multicolumn{5}{|l|}{ Ji-cheon in Cheongyang-gun } \\
\hline Zacco temminckii & 29 & $16(55.2)$ & $1-25$ & 6.9 \\
\hline Hemibarbus longirostris & 13 & $10(76.9)$ & 9-332 & 4.1 \\
\hline Pseudogobio esocinus & 11 & $10(90.9)$ & $3-150$ & 36.3 \\
\hline Zacco platypus & 4 & $4(100)$ & $1-60$ & 16.8 \\
\hline Pungtungia herzi & 3 & $2(66.7)$ & $2-4$ & 3.0 \\
\hline Carassius auratus & 3 & $2(66.7)$ & $5-10$ & 7.5 \\
\hline Pseudobagrus koreanus & 1 & $1(100)$ & - & 1.0 \\
\hline Sarcocheilichthys nigripinnis & 1 & $1(100)$ & - & 2.0 \\
\hline Subtotal & 65 & $46(69.2)$ & $1-332$ & 32.7 \\
\hline
\end{tabular}


Table 2. Continued

\begin{tabular}{lcccc}
\hline Locality and fish sp. & $\begin{array}{c}\text { No. of } \\
\text { fish examined }\end{array}$ & $\begin{array}{c}\text { No. (\%) of } \\
\text { fish infected }\end{array}$ & \multicolumn{2}{c}{ No. of MsMc detected } \\
\hline Nonsan-cheon in Nonsan-si & & & & Range \\
Opsariichthys uncirostris & 7 & $3(42.9)$ & $2-13$ & 6.3 \\
Hemiculter eigenmanni & 6 & $1(16.7)$ & - & 1.0 \\
Pseudorasbora parva & 2 & $2(100)$ & $1-4$ & 2.5 \\
Subtotal & 15 & $6(40.0)$ & $1-13$ & 4.2 \\
Total & 835 & $432(51.7)$ & $1-457$ & 30.1 \\
\hline
\end{tabular}

Table 3. Infection status of Centrocestus armatus metacercariae (CaMc) in freshwater fish from Geum-gang in Jeollabuk-do and Chungcheongnam-do, Korea

\begin{tabular}{|c|c|c|c|c|}
\hline \multirow{2}{*}{ Locality and fish sp. } & \multirow{2}{*}{$\begin{array}{c}\text { No. of } \\
\text { fish examined }\end{array}$} & \multirow{2}{*}{$\begin{array}{l}\text { No. (\%) of } \\
\text { fish infected }\end{array}$} & \multicolumn{2}{|c|}{ No. of CaMc detected } \\
\hline & & & Range & Average \\
\hline \multicolumn{5}{|c|}{ Juja-cheon in Jinahn-gun, Jeollabuk-do } \\
\hline Zacco platypus & 40 & $24(60.0)$ & $1-1,823$ & 206 \\
\hline Zacco temminckii & 40 & $40(100)$ & $26-1,336$ & 246 \\
\hline Subtotal & 124 & $22(17.7)$ & $1-13$ & 2.2 \\
\hline \multicolumn{5}{|c|}{ Geum-gang in Muju-gun, Jeollabuk-do } \\
\hline Zacco temminckii & 11 & $11(100)$ & $13-506$ & 225 \\
\hline \multicolumn{5}{|l|}{ Geum-gang in Geumsan-gun } \\
\hline Zacco platypus & 38 & $38(100)$ & $101-11,805$ & 3,375 \\
\hline Zacco temminckii & 33 & $33(100)$ & $24-3,706$ & 436 \\
\hline Hemibarbus longirostris & 26 & $3(11.5)$ & $1-2$ & 1.3 \\
\hline Opsariichthys uncirostris & 4 & $4(100)$ & $12-562$ & 255 \\
\hline Pseudogobio esocinus & 6 & $1(16.7)$ & - & 1.0 \\
\hline Acanthorhodeus gracilis & 1 & $1(100)$ & - & 21.0 \\
\hline Subtotal & 124 & $22(17.7)$ & $1-13$ & 2.2 \\
\hline \multicolumn{5}{|l|}{ Yugu-cheon in Gongju-si } \\
\hline Zacco platypus & 59 & $59(100)$ & $2,000-43,340$ & 7,019 \\
\hline Acheilognathus lanceolatus & 32 & $5(15.6)$ & $1-49$ & 12.0 \\
\hline Opsariichthys uncirostris & 18 & $18(100)$ & $182-5,240$ & 871 \\
\hline Acheilognathus rhombeus & 15 & $1(6.7)$ & - & 4.0 \\
\hline Hemibarbus longirostris & 7 & $2(28.6)$ & $1-2$ & 1.5 \\
\hline Subtotal & 131 & $85(64.9)$ & $1-43,340$ & 5,057 \\
\hline \multicolumn{5}{|l|}{ Ji-cheon in Cheongyang-gun } \\
\hline Pseudogobio esocinus & 11 & $2(18.2)$ & $3-8$ & 5.5 \\
\hline Zacco temminckii & 29 & $29(100)$ & $7-509$ & 98.6 \\
\hline Acheilognathus koreensis & 10 & $10(100)$ & $27-456$ & 192 \\
\hline Zacco platypus & 4 & $4(100)$ & $128-1,637$ & 754 \\
\hline Subtotal & 43 & $43(100)$ & $7-1,637$ & 181 \\
\hline \multicolumn{5}{|l|}{ Nonsan-cheon in Nonsan-si } \\
\hline Opsariichthys uncirostris & 7 & $2(28.6)$ & $1-2$ & 1.5 \\
\hline Total & 331 & 206 (62.2) & $1-21,510$ & 751 \\
\hline
\end{tabular}

Geumsan-gun, Chungcheongnam-do. Echinostoma spp. metacercariae were detected in $19.7 \%$ fishes in positive fish species from 5 survey regions, and their mean intensity was about 10 per fish infected. However, the Korean dark sleepers, O. platycephala, from Yugu-cheon in Gongju-si were revealed 100\% prevalence and about 48 metacercarial intensity. The metacer- cariae of C. complanatum were found in fishes from only 2 survey regions, Yugu-cheon in Gongju-si and Geum-gang in Geumsan-gun, Chungcheongnam-do. Especially, their endemicity was relatively high in fishes from Yugu-cheon in Gongju-si, Chungcheongnam-do.

The fish collection is one of the important factors in the 
Table 4. Infection status of Echinostoma spp. metacercariae (EsMc) in freshwater fish from Geum-gang in Jeollabuk-do and Chungcheongnam-do, Korea

\begin{tabular}{|c|c|c|c|c|}
\hline \multirow{2}{*}{ Locality and fish sp. } & \multirow{2}{*}{$\begin{array}{c}\text { No. of } \\
\text { fish examined }\end{array}$} & \multirow{2}{*}{$\begin{array}{l}\text { No. (\%) of } \\
\text { fish infected }\end{array}$} & \multicolumn{2}{|c|}{ No. of EsMc detected } \\
\hline & & & Range & Average \\
\hline \multicolumn{5}{|c|}{ Juja-cheon in Jinahn-gun, Jeollabuk-do } \\
\hline Pungtungia herzi & 25 & $1(4.0)$ & - & 1.0 \\
\hline \multicolumn{5}{|c|}{ Geum-gang in Muju-gun, Jeollabuk-do } \\
\hline Pungtungia herzi & 35 & $5(14.3)$ & $1-2$ & 1.2 \\
\hline \multicolumn{5}{|l|}{ Geum-gang in Geumsan-gun } \\
\hline Pseudogobio esocinus & 35 & $2(5.7)$ & - & 1.0 \\
\hline Hemibarbus longirostris & 26 & $3(11.5)$ & - & 1.0 \\
\hline Coreoperca herzi & 23 & $1(4.3)$ & - & 1.0 \\
\hline Odontobutis platycephala & 22 & $8(36.4)$ & $1-13$ & 3.5 \\
\hline Sarcocheilichthys nigripinnis & 8 & $4(50.0)$ & $1-4$ & 2.5 \\
\hline Pungtungia herzi & 6 & $2(33.3)$ & - & 1.0 \\
\hline Sarcocheilichthys variegatus & 3 & $1(33.3)$ & - & 1.0 \\
\hline Acanthorhodeus gracilis & 1 & $1(100)$ & - & 1.0 \\
\hline Subtotal & 124 & $22(17.7)$ & $1-13$ & 2.2 \\
\hline \multicolumn{5}{|l|}{ Yugu-cheon in Gongju-si } \\
\hline Acheilognathus lanceolatus & 32 & $2(6.3)$ & - & 1.0 \\
\hline Pungtungia herzi & 22 & $9(40.9)$ & $1-9$ & 2.4 \\
\hline Pseudogobio esocinus & 20 & $4(20.0)$ & $1-3$ & 2.0 \\
\hline Odontobutis platycephala & 10 & $10(100)$ & $5-123$ & 47.7 \\
\hline Sarcocheilichthys variegatus & 5 & $1(20.0)$ & - & 3.0 \\
\hline Subtotal & 89 & $26(29.2)$ & 3-8 & 5.5 \\
\hline \multicolumn{5}{|l|}{ Ji-cheon in Cheongyang-gun } \\
\hline Pseudogobio esocinus & 11 & $2(18.2)$ & $3-8$ & 5.5 \\
\hline Total & 331 & $206(62.2)$ & $1-21,510$ & 751 \\
\hline
\end{tabular}

Table 5. Infection status of Clinostomum complanatum metacercariae (CcMc) in freshwater fish from Geum-gang in Chungcheongnamdo, Korea

\begin{tabular}{|c|c|c|c|c|}
\hline \multirow{2}{*}{ Locality and fish sp. } & \multirow{2}{*}{$\begin{array}{c}\text { No. of } \\
\text { fish examined }\end{array}$} & \multirow{2}{*}{$\begin{array}{l}\text { No. (\%) of } \\
\text { fish infected }\end{array}$} & \multicolumn{2}{|c|}{ No. of CcMc detected } \\
\hline & & & Range & Average \\
\hline \multicolumn{5}{|l|}{ Geum-gang in Geumsan-gun } \\
\hline Squalidus japonicus coreanus & 5 & $2(40.0)$ & - & 1.0 \\
\hline Acheilognathus yamatsutae & 7 & $3(42.9)$ & - & 1.0 \\
\hline Hemibarbus longirostris & 6 & $1(16.7)$ & - & 1.0 \\
\hline Hemibarbus labeo & 1 & $1(100)$ & - & 2.0 \\
\hline Subtotal & 19 & $7(36.8)$ & $1-2$ & 1.1 \\
\hline \multicolumn{5}{|l|}{ Yugu-cheon in Gongju-si } \\
\hline Acheilognathus lanceolatus & 72 & $62(86.1)$ & $1-64$ & 1.3 \\
\hline Hemibarbus Iongirostris & 32 & $2(6.3)$ & - & 2.0 \\
\hline Acheilognathus yamatsutae & 20 & $19(95.0)$ & $1-61$ & 18.1 \\
\hline Pungtungia herzi & 17 & $5(29.4)$ & $1-18$ & 4.6 \\
\hline Carassius auratus & 10 & $2(20.0)$ & $4-27$ & 15.5 \\
\hline Squalidus gracilis majimae & 1 & $1(100)$ & - & 1.0 \\
\hline Subtotal & 152 & $91(59.9)$ & $1-64$ & 12.1 \\
\hline Total & 171 & $98(57.3)$ & $1-64$ & 11.3 \\
\hline
\end{tabular}

metacercarial surveys for the trematode epidemiology. Total 1,161 fishes in 41 species from 6 survey regions in the water systems of Geum-gang were examined in this study. The amount of fish samples was considerably different by the survey regions from 44 fishes in 11 species (Nonsan-cheon in Nonsan-si) to 386 fishes in 22 species (Geum-gang in Geum- 
san-gun). Furthermore, 28 (68.3\%) fish species were examined with below 20 in numbers, and the fish species examined with over 50 fish individuals was only 9 (22.0\%) species, i.e., Z. platypus ( $\mathrm{n}=141)$, H. longirostris (138), P. esocinus (136), Z. temminckii (113), P. herzi (101), A. lanceolatus (73), C. herzi (58), O. platycephala (57), and C. auratus (52). Accordingly, there are some differences in the fish collection by the survey regions and fish species in this study. These differences are unable to compare the infection status of ZTM by the survey regions in this study and previous studies. However, this study is able to reveal the general trends on the ZTM infections in fishes from the water systems of Geum-gang.

It has been known that the infection status of CsMc is showed a certain tendency in positive fish species from endemic sites, Wi-cheon in Gunwi-gun, Gyeongsangbuk-do and Yang-cheon in Sancheong-gun, Gyeongsangnam-do, according to the subfamily groups, i.e., Gobioninae, Acheilognathinae and Rasborinae, in the Cyprinidae fish hosts [11,12]. In this study, $30(73.2 \%)$ fish species were the members of order Cypriniformes, and 26 (86.7\%) out of 30 species were belonging to the family Cyprinidae (13 species in Gobioninae, 6 species in Acheilognathinae, 3 species in Rasborinae, 2 species in Cultrinae, 1 species in Leuciscinae and 1 species in Cyprininae) [22]. Among total 893 fish in family Cyprinidae, 454 (50.8\%) ones were the members of Gobioninae, 147 (16.5\%) were those of Acheilognathinae, 283 (31.7\%) were those of Rasborinae, and 9 (1.0\%) ones were those of other 3 subfamilies. A total of 122 (37.2\%) out of 328 fish in 14 species, i.e., P. herzi, S. variegatus, S. nigripinnis, S. japonicus coreanus, $S$ gracilis majimae, P. parva, P. esocinus, H. longirostris, H. eigenmanni, C. splendidus, A. yamatsutae, Z. platypus, O. uncirostris and S. scherzeri, were infected with CsMc, and 119 (98.5\%) fish in 13 (92.9\%) species were the members of Cyprinidae. They all had been listed as the second intermediate hosts of $C$. sinensis in Korea [23,24]. On the other hand, the striped shinner, $P$. herzi, is to be known as an index fish species to check the endemicity of CsMc. Because of this fish species broadly lives in the water systems of Korea and is highly susceptible to CsMc. In this study, 52 (98.1\%) out of 53 P. herzi (35 fish from Geum-gang in Mujugun, Jeollabuk-do, 15 ones from Geum-gang in Geumsan-gun and 3 ones from Ji-cheon in Cheongyang-gun, Chungcheongnam-do) were infected with 93.5 CsMc per fish infected, whereas 48 ( 25 fish from Juja-cheon in Jinahn-gun, Jeollabuk-do, 22 ones from Yugu-cheon in Gongju-si and only one from Nonsan-cheon in Nonsan-si, Chungcheongnam-do) out of 101 P. herzi examined were negative with $\mathrm{CsMc}$. The endemicities with CsMc were very low in other 13 fish species. Therefore, the infection tendency with CsMc could not show by the subfamily groups in the Cyprinidae fish hosts in this study.

The river basin of Geum-gang was known as the endemic area of metagonimiasis as well as clonorchiasis [16-20]. It was also known that metagonimiasis is caused by M. miyatai and the main infection sources of this endemic disease are chubs, Z. platypus and Z. temminckii, in this region [16-18]. In this study, the endemicity of Metagonimus spp. metacercariae was not so high in 2 chub fish species. Prevalences were about $71 \%$ (100/141 Z. platypus examined) and $68 \%$ (77/113 Z. temminckii examined), but infection intensities were about 31 and 6 per fish infected. High prevalence and low burden with Metagonims spp. metacercariae in chubs like in this study were also shown in most of rivers and streams in Gangwon-do. However, chubs from Joyang-gang (Jeongseon-gun) and Hantan-gang (Cheorwon-gun) revealed somewhat higher emdemicities for Metagonims spp. metacercariae [7,8].

The chub fish species, Z. platypus, Z. koreanus and Z. temminckii, are known to be the susceptible fish hosts for C. armatus metacercariae (CaMc) in Korea [23-25]. In this study, the high endemicities with CaMc were shown in Z. platypus from Geum-gang (100\% prevalence and over 3,300 CaMc intensity) in Geumsan-gun and Yugu-cheon (100\% prevalence and over 7,000 CaMc intensity) in Gongju-si, Chungcheongnam-do. In a nation-wide survey of CaMc [25], the prevalences were very high, 93.7-100\% (av. 97.1\%), in chub fish species, Zacco spp., from all surveyed sites. However, their infection intensities were more or less different by the surveyed areas and fish species. They were most high in Nakdong-gang in Gyeongsangnam-do (av., 4,201), and followed by Geum-gang $(2,343)$, Nakdong-gang in Gyeongsangbuk-do $(1,623)$, Han-gang $(1,564)$, Tamjin-gang $(1,550)$, Yeongsan-gang $(1,493)$, streams in the east coast $(1,028)$, Seomjin-gang (488) and Mangyeonggang and Dongiin-gang (170). And then they were slightly higher in Z. platypus (av. 2,109) than in Z. temminckii $(1,567)$ [25].

Infection status of Echinostoma spp. metacercariae (EsMc) was not so high in freshwater fish from Geum-gang in this study. However, it (100\% prevalence and about 48 EsMc intensity) was relatively high in Korean dark sleeper, $O$. platycephala, from Yugu-cheon in Gongju-si, Chungcheongnam-do. Ahn et al. [26] detected a total of 32 Echinostoma hortense (= Isthmiophora hortensis) metacercariae (IhMc) in $10(27.8 \%)$ out of 36 
dark sleepers, O. interrupta, from Seom-gang in Wonseonggun, Gangwon-do, Korea. Ahn and Ryang [27] found IhMc in $4(22.2 \%)$ out of 18 dark sleepers from Namhan-gang in Gyeoggi-do and Gangwon-do. Lee et al. [28] detected IhMc in only $1(2.3 \%)$ out of 44 O. interrupta from Cheongsong-gun, Gyeongsangbuk-do, Korea. Ryang [29] detected IhMc in 11 (20.3\%) out of 54 dark sleepers from Chungju-ho (ho means lake) and the upper streams of Namhan-gang. Sohn et al. [8] reported relatively high prevalence $(96.7 \%)$ and infection intensity (22 IhMc per fish infected) in $30 \mathrm{O}$. platycephala from Munsan-cheon in Paju-si, Gyeonggi-do. Recently, Sohn et al. [30] broadly surveyed the infection status with IhMc in dark sleepers, Odontobutis species, from some water systems of Korea. Infection status of IhMc in dark sleepers from Yugu-cheon was already included in Sohn et al. [30], and it was much higher than the findings of other previous studies [26-29].

In this study, C. complanatum metacercariae (CcMc) were detected in fishes from only 2 survey sites, Geum-gang in Geumsan-gun and Yugu-cheon in Gongju-si, Chungcheongnam-do. Overall prevalences in fishes from 2 sites were $36.8 \%$ and $59.9 \%$ in positive fish species, and intensities of infection were 1.1 and 12.1 per fish infected. Especially, in 2 species of bitterling, Acheilognathus lanceolatus and A. yamatsutae, from Yugucheon, prevalences were $86.1 \%$ and $95.0 \%$, and intensities of infection were 11 and 18 per fish infected. Recently, Sohn et al. [31] broadly surveyed the infection status with CcMc in fishes from water systems of Nakdong-gang in Korea. In Sohn et al. [31], the infection tendency with CcMc was showed by the fish groups in fishes from Yang-cheon in Sancheong-gun Gyeongsangnam-do. The prevalence was most high in Squalidus spp. (97.7\%) and followed by acheilognathinid fish (66.8\%), P. herzi (52.0\%), rasborinid fish (39.6\%) and Hemibarbus spp. (25.9\%). The intensity of infection was also most high in Squalidus spp. (av. 27 per fish infected) and followed by acheilognathinid fish (9), P. herzi (7), rasborinid fish (4), and Hemibarbus spp. (3). By the present study, 2 species of bitterling, A. lanceolatus and A. yamatsutae, from Yugu-cheon in Gongju-si, are to be heavily infected with CcMc as the members of acheilognathinid fish.

Conclusively, more than 5 species, i.e., C. sinensis, Metagonimus spp., C. armatus, Echinostoma spp. and C. complanatum, of ZTM were found in fishes from the water systems of Geumgang in this study, but their overall endemicities were not so high. The endemicity of ZTM was variable and more or less different by the survey sites and fish species. The metacercariae of $C$. sinensis were relatively endemic in striped shiner, $P$. herzi, from Geum-gang in Muju-gun, Jeollabuk-do and in Geumsangun, Chungcheongnam-do. The metacercariae of $C$. armatus were highly endemic in pale chub, Z. platypus, from Yugucheon in Gongju-si, and Geum-gang in Geumsan-gun, Chungcheongnam-do. Echinostome metacercariae were prevalent in Korean dark sleeper, O. platycephala, from Yugu-cheon in Gongju-si. The metacercariae of $C$. complanatum were relatively endemic in 2 species of bitterling, A. lanceolatus and A. yamatsutae, from Yugu-cheon in Gongju-si, Chungcheongnam-do.

\section{ACKNOWLEDGMENTS}

This study was supported by an Anti-Communicable Diseases Control Program, 2013 (Studies on the biological resources of human infecting trematodes and their larval infections in intermediate hosts), 2014 (Investigation of fishborne parasites and acquisition of their biological resources in the southern regions of Korea), and 2015 (Investigation of fishborne parasites and acquisition of their biological resources in the eastern regions of Korea) of National Research Institute of Health (NRIH), Korea Centers for Disease Control and Prevention (KCDCP). We thank Jung-A Kim and Hee-Ju Kim, Department of Parasitology and Tropical Medicine, Gyeongsang National University College of Medicine, Jinju, Korea, for their help in fish examinations.

\section{CONFLICT OF INTEREST}

The authors have no conflicts of interest concerning the work reported in this paper.

\section{REFERENCES}

1. Korea Centers for Disease Control and Prevention. Korea National Institute of Health. National survey of the prevalence of intestinal parasitic infections in Korea, 2012. The 8th Report. Osong, Korea, 2013.

2. Cho SH, Lee KY, Lee BC, Cho PY, Cheun HI, Hong ST, Sohn WM, Kim TS. Prevalence of clonorchiasis in southern endemic areas of Korea in 2006. Korean J Parasitol 2008; 46: 133-137. https://doi.org/10.3347/kjp.2008.46.3.133

3. Kim HK, Cheun HI, Chung BS, Lee KY, Kim TS, Lee SE, Lee WJ, Cho SH. Prevalence of Clonorchis sinensis infections along the five major rivers in Republic of Korea, 2007. Public Health Res Perspect 2010; 1: 43-49. https://doi.org/10.1016/j.phrp.2010.12.010

4. June KJ, Cho SH, Lee WJ, Kim C, Park KS. Prevalence and risk fac- 
tors of clonorchiasis among the populations served by primary healthcare posts along five major rivers in South Korea. Osong Public Health Res Perspect 2013; 4: 21-26. https://doi.org/10.1016/ j.phrp.2012.12.002

5. Jeong YI, Shin HE, Lee SE, Cheun HI, Ju JW, Kim JY, Park MY, Cho SH. Prevalence of Clonorchis sinensis infection among residents along 5 major rivers in the Republic of Korea. Korean J Parasitol 2016; 54: 215-219. https://doi.org/10.3347/kjp.2016.54.2.215

6. Cho SH, Sohn WM, Na BK, Kim TS, Kong Y, Eom K, Seok WS, Lee T. Prevalence of Clonorchis sinensis metacercariae in freshwater fish from three latitudinal regions of the Korean Peninsula. Korean J Parasitol 2011; 49: 385-398. https://doi.org/10.3347/kjp.2011. 49.4.385

7. Cho SH, Lee WJ, Kim TS, Seok WS, Lee TJ, Jeong KJ, Na BK, Sohn WM. Prevalence of zoonotic trematode metacercariae in freshwater fish from Gangwon-do, Korea. Korean J Parasitol 2014; 52: 399-412. https://doi.org/10.3347/kjp.2014.52.4.399

8. Sohn WM, Na BK, Cho SH, Lee SW, Choi SB, Seok WS. Trematode metacercariae in freshwater fish from water systems of Hantangang and Imjingang in Republic of Korea. Korean J Parasitol 2015; 53: 289-298. https://doi.org/10.3347/kjp.2015.53.3.289

9. Sohn WM, Na BK, Cho SH, Park MY, Kim CH, Hwang MA, No KW, Yoon KB, Lim HC. Prevalence of Clonorchis sinensis metacercariae in fish from water systems of Seomjin-gang (river). Korean J Parasitol 2017; 55: 305-312. https://doi.org/10.3347/kjp.2017.55.3.305

10. Yoon KB, Lim HC, Jeon DY, Park S, Cho SH, Ju JW, Shin SS, Na $\mathrm{BK}$, Sohn WM. Infection status with Clonorchis sinensis metacercariae in fish from Tamjin-gang (river) in Jeollanam-do, Republic of Korea. Korean J Parasitol 2018; 56: 183-188. https://doi. org/10.3347/kjp.2018.56.2.183

11. Sohn WM, Na BK, Cho SH, Ju JW, Son DC. Prevalence and intensity of Clonorchis sinensis metacercariae in freshwater fish from Wicheon stream in Gunwi-gun, Gyeongsangbuk-do, Korea. Korean J Parasitol 2018; 56: 41-48. https://doi.org/10.3347/kjp.2018.56.1.41

12. Sohn WM, Na BK, Cho SH, Ju JW. Infection status with Clonorchis sinensis metacercariae in fish from Yangcheon (Stream) in Sancheong-gun, Gyeongsangnam-do, Korea. Korean J Parasitol 2019; 57: 145-152. https://doi.org/10.3347/kjp.2019.57.2.145

13. Sohn WM, Na BK, Cho SH, Lee SW. Infection status with digenetic trematode metacercariae in fishes from coastal lakes in Gangwon-do, Republic of Korea. Korean J Parasitol 2019; 57: 681-690. https://doi.org/10.3347/kjp.2019.57.6.681

14. Sohn WM, Na BK. Infections with digenetic trematode metacercariae in freshwater fishes from two visiting sites of migratory birds in Gyeongsangnam-do, Republic of Korea. Korean J Parasitol 2019; 57: 273-281. https://doi.org/10.3347/kjp.2019.57.3.273

15. Geum-gang in Jeollabuk-do and Chungcheongnam-do (South Korea) in Wikipedia - The free ency $\neg$ clopedia: http://en.wikipedia.org.

16. Kim CH. Study on the Metagonimus sp. in Gum river basin, Chungchungnam-do, Korea. Korean J Parasitol 1980; 18: 215-228 (in Korean). https://doi.org/10.3347/kjp.1980.18.2.215

17. Kim CH, Kim NM, Lee CH, Park JS. Studies on the Metagonimus fluke in the Daecheong reservoir and the upper stream of Gum river, Korea. Korean J Parasitol 1987; 25: 69-82 (in Korean). https://doi.org/10.3347/kjp.1987.25.1.69

18. Lee GS, Cho IS, Lee YH, Noh HJ, Shin DW, Lee SG, Lee TY. Epidemiological study of clonorchiasis and metagonimiasis along the Geum-gang (river) in Okcheon-gun (county), Korea. Korean J Parasitol 2002; 40: 9-16. https://doi.org/10.3347/kjp.2002.40.1.9

19. Park DS, Na SJ, Cho SH, June KJ, Cho YC, Lee YH. Prevalence and risk factors of clonorchiasis among residents of riverside areas in Muju-gun, Jeollabuk-do, Korea. Korean J Parasitol 2014; 52: 391-397. https://doi.org/10.3347/kjp.2014.52.4.391

20. Shin HE, Lee MR, Ju JW, Jeong BS, Park MY, Lee KS, Cho SH. Epidemiological and clinical parameters features of patients with clonorchiasis in the Geum River basin, Republic of Korea. Interdiscip Perspect Infect Dis. 2017; 2017: 7415301 https://doi.org/10. 1155/2017/7415301

21. Choe S, Park H, Lee D, Kang Y, Jeon HK, Eom KS. Infections with digenean trematode metacercariae in two invasive alien fish, Micropterus salmoides and Lepomis macrochirus, in two rivers in Chungcheongbuk-do, Republic of Korea. Korean J Parasitol 2018; 56: 509-513. https://doi.org/10.3347/kjp.2018.56.5.509

22. Kim IS, Kang EJ. Coloured Fishes of Korea. Seoul, Korea. Academy Publishing Company. 1993, pp. 1-477. (in Korean).

23. Sohn WM. Fish-borne zoonotic trematode metacercariae in the Republic of Korea. Korean J Parasitol 2009; 47 (suppl): 103-113. https://doi.org/10.3347/kjp.2009.47.S.S103

24. Sohn WM. Invertebrate Fauna of Korea Vol. 6, No. 1. Trematodes. Incheon, Korea. The National Institute of Biological Resources. 2013, pp. 1-125.

25. Sohn WM, Na BK, Cho SH, Ju JW, Kim CH, Yoon KB, Kim JD, Son DC, Lee SW. Infections with Centrocestus armatus metacercariae in fishes from water systems of major rivers in Republic of Korea. Korean J Parasitol 2018; 56: 341-349. https://doi.org/10.3347/ kjp.2018.56.4.341

26. Ahn YK, Ryang YS, Chung PR, Lee KT. Echinostoma hortense metacercariae naturally encysted in Odontobutis obscura interrupta (a freshwater fish) and experimental infection to rats. Korean J Parasitol 1985; 23: 230-235 (in Korean). https://doi.org/10.3347/ kjp.1985.23.2.230

27. Ahn YK, Ryang YS. Experimental and epidemiological studies on the life cycle of Echinostoma hortense Asada, 1926 (Trematoda: Echinostomatidae). Korean J Parasitol 1986; 24: 121-136 (in Korean). https://doi.org/10.3347/kjp.1986.24.2.121

28. Lee SK, Chung NS, Ko IH, Sohn WM, Hong ST, Chai JY, Lee SH. An epidemiological survey of Echinostoma hortense infection in Chongsong-gun, Kyongbuk province. Korean J Parasitol 1988; 26: 199-206 (in Korean) https://doi.org/10.3347/kjp.1988.26.3.199.

29. Ryang YS. Studies on Echinostoma spp. in the Chungju Reservoir and upper stream of the Namhan River. Korean J Parasitol 1990; 28: 221-233 (In Korean). https://doi.org/10.3347/kjp.1990.28.4.221

30. Sohn WM, Na BK, Cho SH, Ju JW. Infections status of Isthmiophora hortensis metacercariae in dark sleepers, Odontobutis species, from some water systems of the Republic of Korea. Korean J Parasitol 
2018; 56: 633-637. https://doi.org/10.3347/kjp.2018.56.6.633

31. Sohn WM, Na BK, Cho SH. Infection status with Clinostomum complanatum metacercariae in fish from water systems of Nakdong- gang (River) in Korea. Korean J Parasitol 2019; 57: 389-397. https:// doi.org/10.3347/kjp.2019.57.4.389 
